\title{
Synthesis, characterization and photochemistry of a new heptamolybdate supported magnesium-aqua coordination complex
}

\author{
SAVITA S. KHANDOLKAR ${ }^{\mathrm{a}}$, PALLEPOGU RAGHAVAIAH ${ }^{\mathrm{b}}$ and \\ BIKSHANDARKOIL R SRINIVASAN ${ }^{\mathrm{a}, *}$ \\ aDepartment of Chemistry, Goa University, Goa 403 206, India \\ ${ }^{b}$ Department of Chemistry, Dr. Harisingh Gour University, Sagar - 470003 (M.P.), India \\ e-mail: srini@unigoa.ac.in
}

Dedicated to Prof. Dr. S.K. Paknikar on the occasion of his $80^{\text {th }}$ birthday

MS received 14 April 2015; revised 8 June 2015; accepted 12 June 2015

\begin{abstract}
The synthesis, crystal structure, redox characteristics and photochemistry of a new heptamolybdate supported magnesium-aqua coordination complex viz. (hmtH) $2\left[\left\{\mathrm{Mg}\left(\mathrm{H}_{2} \mathrm{O}\right)_{5}\right\}_{2}\left\{\mathrm{Mo}_{7} \mathrm{O}_{24}\right\}\right] \cdot 3 \mathrm{H}_{2} \mathrm{O} \mathbf{1}(\mathrm{hmt}$ $=$ hexamethylenetetramine) is reported. The cyclic voltammogram reveals quasireversible redox behaviour while the degradation of rhodamine $B(\mathrm{RhB})$ by $\mathbf{1}$ under sunlight irradiation indicates its photocatalytic activity. In the crystal structure of $\mathbf{1}$, two $\left[\mathrm{Mg}\left(\mathrm{H}_{2} \mathrm{O}\right)_{5}\right]^{2+}$ units are linked by a $\mu_{2}$-bridging bidentate heptamolybdate ligand resulting in a heptamolybdate supported magnesium-aqua coordinated dianionic complex $\left[\left\{\mathrm{Mg}\left(\mathrm{H}_{2} \mathrm{O}\right)_{5}\right\}_{2}\left\{\mathrm{Mo}_{7} \mathrm{O}_{24}\right\}\right]^{2-}$ charge balanced by two $(\mathrm{hmtH})^{+}$cations. The cations, anions and the lattice water molecules are linked by several hydrogen bonding interactions.
\end{abstract}

Keywords. Heptamolybdate; Hexamethylenetetramine; $\mu_{2}$-bridging bidentate ligand; Photocatalysis; Cyclic voltammogram.

\section{Introduction}

The study of polyoxometalates (POMs) is a frontier area of research in view of the rich structural diversity and interesting properties exhibited by the POMs. ${ }^{1-20}$ Among the POMs of the early transition metals, Mobased POMs known as polyoxomolybdates represents diverse structures. Polyoxomolybdate synthesis is normally performed by acidification of an aqueous alkaline $\left[\mathrm{MoO}_{4}\right]^{2-}$ solution resulting in the condensation of the tetrahedral $\left\{\mathrm{MoO}_{4}\right\}$ units. ${ }^{21}$ The final product of the acidification is $\mathrm{MoO}_{3}$, while the first product ( $\left.\sim \mathrm{pH} 6\right)$, is the heptamolybdate $\left[\mathrm{Mo}_{7} \mathrm{O}_{24}\right]^{6-}$ anion ${ }^{22}$ which has been isolated with a variety of counter cations. ${ }^{23}$

The ability of $\left[\mathrm{Mo}_{7} \mathrm{O}_{24}\right]^{-6}$ to function as a pure "inorganic ligand" has made it possible to use it as a building block $^{24}$ for the synthesis of new materials. A literature survey (table 1) reveals the rich coordination chemistry of the heptamolybdate ligand. The flexibility of heptamolybdate anion to exist in different structural environments and to adopt different binding modes depending upon the steric requirements of the heterometal leads to different heterometallic structural motifs. ${ }^{24-33}$

\footnotetext{
*For correspondence
}

Although many examples of heptamolybdate coordinating to $d$ and $f$-block metal ions are known in the literature, the only known alkaline earth heptamolybdate is $(\mathrm{ImH})_{4}\left[\mathrm{Ca}\left(\mathrm{H}_{2} \mathrm{O}\right)_{6}\left(\mu_{2}-\mathrm{Mo}_{7} \mathrm{O}_{24}\right)\right] \cdot 2(\mathrm{Im}) \cdot 3 \mathrm{H}_{2} \mathrm{O} \cdot{ }^{29}$ In view of the preference of alkaline earths to bind to hard oxygen donor ligands, heptamolybdate can be expected to coordinate to alkaline earths under appropriate reaction conditions. Hence we have investigated the reaction of $\mathrm{Mg}(\mathrm{II})$ with $\left[\mathrm{Mo}_{7} \mathrm{O}_{24}\right]^{6-}$ in the presence of hexamethylenetetramine (hmt). The result of this study describing the synthesis, structure characterization and properties of a new heptamolybdate supported magnesium-aqua coordination complex $(\mathrm{hmtH})_{2}\left[\left\{\mathrm{Mg}\left(\mathrm{H}_{2} \mathrm{O}\right)_{5}\right\}_{2}\left\{\mathrm{Mo}_{7} \mathrm{O}_{24}\right\}\right] \cdot 3 \mathrm{H}_{2} \mathrm{O} \mathbf{1}$ is reported herein.

\section{Experimental}

\subsection{Materials and methods}

All the chemicals employed in this work were used as received without any further purification. Infrared spectra of the samples diluted in $\mathrm{KBr}$ were recorded in the region $4000-400 \mathrm{~cm}^{-1}$ using a Shimadzu (IR Prestige21) FT-IR Spectrometer, at a resolution of $4 \mathrm{~cm}^{-1}$. Raman spectra were recorded using Horiba Jobin-Yvon 
Table 1. Coordination geometry and different types of hetero-metallic unit of heptamolybdate compounds.

\begin{tabular}{|c|c|c|c|c|c|}
\hline $\begin{array}{l}\text { Sr. } \\
\text { No }\end{array}$ & Compound & $\begin{array}{l}\text { Space } \\
\text { Group }\end{array}$ & $\begin{array}{l}\text { Hetero- } \\
\text { metallic unit }\end{array}$ & $\begin{array}{c}\text { Coordination } \\
\text { geometry of } \\
\text { heterometal ' } \mathrm{M} \text { ' }\end{array}$ & Ref \\
\hline 1 & $(2-\mathrm{apH})_{4}\left[\mathrm{Co}\left(\mathrm{H}_{2} \mathrm{O}\right)_{5} \mathrm{Mo}_{7} \mathrm{O}_{24}\right] \cdot 9 \mathrm{H}_{2} \mathrm{O}$ & $P n a 2_{1}$ & $\left\{\mathrm{MMo}_{7}\right\}$ & Octahedral & 24 \\
\hline 2 & $\mathrm{Na}\left(\mathrm{NH}_{4}\right)\left[\mathrm{bppH}_{2}\right]_{2}\left[\mathrm{Mo}_{7} \mathrm{O}_{24}\right] \cdot 8 \mathrm{H}_{2} \mathrm{O}$ & $P 2_{1} / m$ & $\left\{\mathrm{MMo}_{7}\right\}$ & Octahedral & 25 \\
\hline 3 & $\left(\mathrm{NH}_{4}\right)_{4}\left[\mathrm{Ru}(\mathrm{DMSO})_{3} \mathrm{Mo}_{7} \mathrm{O}_{24}\right] \cdot 6.5 \mathrm{H}_{2} \mathrm{O}$ & $C 2 / c$ & $\left\{\mathrm{MMo}_{7}\right\}$ & $\begin{array}{c}\text { Trigonal } \\
\text { Antiprismatic }\end{array}$ & 26 \\
\hline 4 & $\left(\mathrm{NH}_{4}\right)_{4}\left[\mathrm{Os}(\mathrm{DMSO})_{3} \mathrm{Mo}_{7} \mathrm{O}_{24}\right] \cdot 4.5 \mathrm{H}_{2} \mathrm{O}$ & $C 2 / c$ & $\left\{\mathrm{MMo}_{7}\right\}$ & $\begin{array}{c}\text { Trigonal } \\
\text { Antiprismatic }\end{array}$ & 26 \\
\hline 5 & $\left.[2-\mathrm{ampH}]_{4}\left[\left\{\mathrm{Zn}-\mathrm{H}_{2} \mathrm{O}\right)_{5}\right\} \mathrm{Mo}_{7} \mathrm{O}_{24}\right] \cdot 9 \mathrm{H}_{2} \mathrm{O}$ & Pnma & $\left\{\mathrm{MMo}_{7}\right\}$ & Octahedral & 27 \\
\hline 6 & {$[3-\mathrm{ampH}]_{4}\left[\left\{\mathrm{Zn}(3-\mathrm{ampy})\left(\mathrm{H}_{2} \mathrm{O}\right)_{4}\right\} \mathrm{Mo}_{7} \mathrm{O}_{24}\right] \cdot 4 \mathrm{H}_{2} \mathrm{O}$} & $C c$ & $\left\{\mathrm{MMo}_{7}\right\}$ & $\begin{array}{l}\text { Distorted } \\
\text { Octahedral }\end{array}$ & 27 \\
\hline 7 & {$[3-\mathrm{ampH}]_{4}\left[\left\{\mathrm{Co}(3-\mathrm{ampy})\left(\mathrm{H}_{2} \mathrm{O}\right)_{4}\right\} \mathrm{Mo}_{7} \mathrm{O}_{24}\right] \cdot 4 \mathrm{H}_{2} \mathrm{O}$} & $C c$ & $\left\{\mathrm{MMo}_{7}\right\}$ & $\begin{array}{l}\text { Distorted } \\
\text { Octahedral }\end{array}$ & 27 \\
\hline 8 & $\left(\mathrm{NH}_{4}\right)_{6} \mathrm{H}_{2}\left[\mathrm{Cu}\left(\mathrm{C}_{2} \mathrm{O}_{4}\right)_{2} \mathrm{Mo}_{7} \mathrm{O}_{24}\right] \cdot 9 \mathrm{H}_{2} \mathrm{O}$ & $P 2_{1} / m$ & $\left\{\mathrm{MMo}_{7}\right\}$ & $\begin{array}{l}\text { Distorted } \\
\text { Octahedral }\end{array}$ & 28 \\
\hline 9 & $(\operatorname{ImH})_{4}\left[\mathrm{Ca}\left(\mathrm{H}_{2} \mathrm{O}\right)_{6}\left(\mu_{2}-\mathrm{Mo}_{7} \mathrm{O}_{24}\right)\right] \cdot 2(\operatorname{Im}) \cdot 3 \mathrm{H}_{2} \mathrm{O}$ & $C 2 / m$ & $\left\{\mathrm{M}\left(\mathrm{Mo}_{7}\right)_{2}\right\}$ & $\begin{array}{c}\text { Square } \\
\text { Antiprismatic }\end{array}$ & 29 \\
\hline 10 & $(\mathrm{hmtH})_{2}\left[\mathrm{Mn}_{2}\left(\mathrm{H}_{2} \mathrm{O}\right)_{9} \mathrm{Mo}_{7} \mathrm{O}_{24}\right] \cdot 2 \mathrm{H}_{2} \mathrm{O}$ & $C 2 / c$ & $\left\{\mathrm{M}_{2} \mathrm{Mo}_{7}\right\}$ & $\begin{array}{l}\text { Distorted } \\
\text { Octahedral }\end{array}$ & 30 \\
\hline 11 & $(\mathrm{hmtH})_{2}\left[\mathrm{Fe}_{2}\left(\mathrm{H}_{2} \mathrm{O}\right)_{9} \mathrm{Mo}_{7} \mathrm{O}_{24}\right] \cdot 2 \mathrm{H}_{2} \mathrm{O}$ & $C 2 / c$ & $\left\{\mathrm{M}_{2} \mathrm{Mo}_{7}\right\}$ & $\begin{array}{l}\text { Distorted } \\
\text { Octahedral }\end{array}$ & 30 \\
\hline 12 & $\left(\mathrm{hmtH}_{2}\right)_{1.5}\left(\mathrm{ahmtH}_{2}\right)_{0.5}\left[\mathrm{Na}_{2}\left(\mathrm{H}_{2} \mathrm{O}\right)_{5} \mathrm{Mo}_{7} \mathrm{O}_{24}\right] \cdot 4 \mathrm{H}_{2} \mathrm{O}$ & Pnma & $\left\{\mathrm{M}_{2} \mathrm{Mo}_{7}\right\}$ & $\begin{array}{l}\text { Distorted } \\
\text { Octahedral }\end{array}$ & 30 \\
\hline 13 & $(\mathrm{hmtH})_{2}\left[\left\{\left(\mathrm{Zn}\left(\mathrm{H}_{2} \mathrm{O}\right)_{5}\right\}\left\{\mathrm{Zn}\left(\mathrm{H}_{2} \mathrm{O}\right)_{4}\right\}\left\{\mathrm{Mo}_{7} \mathrm{O}_{24}\right\}\right] \cdot 2 \mathrm{H}_{2} \mathrm{O}\right.$ & $C 2 / c$ & $\left\{\mathrm{M}_{2} \mathrm{Mo}_{7}\right\}$ & $\begin{array}{l}\text { Distorted } \\
\text { Octahedral }\end{array}$ & 31 \\
\hline 14 & $\left(h m \mathrm{H}_{2}\right)_{2}\left[\mathrm{Na}_{2}\left(\mathrm{H}_{2} \mathrm{O}\right)_{5}\left(\mathrm{Mo}_{7} \mathrm{O}_{24}\right)\right] \cdot 4 \mathrm{H}_{2} \mathrm{O}$ & Pnma & $\left\{\mathrm{M}_{2} \mathrm{Mo}_{7}\right\}$ & $\begin{array}{l}\text { Distorted } \\
\text { Octahedral }\end{array}$ & 32 \\
\hline 15 & $(\mathrm{hmtH})_{2}\left[\left\{\mathrm{Mg}\left(\mathrm{H}_{2} \mathrm{O}\right)_{5}\right\}_{2}\left\{\mathrm{Mo}_{7} \mathrm{O}_{24}\right\}\right] \cdot 3 \mathrm{H}_{2} \mathrm{O}$ & $C 2 / c$ & $\left\{\mathrm{M}_{2} \mathrm{Mo}_{7}\right\}$ & $\begin{array}{l}\text { Distorted } \\
\text { Octahedral }\end{array}$ & $\begin{array}{l}\text { This } \\
\text { work }\end{array}$ \\
\hline 16 & $\left(\mathrm{NH}_{4}\right)_{28}\left[\mathrm{Ce}_{8}\left(\mathrm{MoO}_{4}\right)_{2}\left(\mathrm{H}_{2} \mathrm{O}\right)_{31}\left(\mathrm{Mo}_{7} \mathrm{O}_{24}\right)_{8}\right] \cdot 74 \mathrm{H}_{2} \mathrm{O}$ & $P \bar{l}$ & $\left\{\mathrm{M}_{8}\left(\mathrm{Mo}_{7}\right)_{8}\right\}$ & Trigonal prism & 33 \\
\hline 17 & $\left(\mathrm{NH}_{4}\right)_{26}\left[\mathrm{CoPr}_{8}\left(\mathrm{MoO}_{4}\right)_{2}\left(\mathrm{H}_{2} \mathrm{O}\right)_{33}\left(\mathrm{Mo}_{7} \mathrm{O}_{24}\right)_{8}\right] \cdot 54 \mathrm{H}_{2} \mathrm{O}$ & $P \bar{l}$ & $\left\{\mathrm{M}_{8}\left(\mathrm{Mo}_{7}\right)_{8} \mathrm{M}\right\}$ & $\begin{array}{c}\text { Distorted } \\
\text { Octahedral, } \\
\text { Tigonal prism }\end{array}$ & 33 \\
\hline 18 & $\left(\mathrm{NH}_{4}\right)_{11.9}\left[\operatorname{Pr}_{4.7}\left(\mathrm{MoO}_{4}\right)\left(\mathrm{H}_{2} \mathrm{O}\right)_{23}\left(\mathrm{Mo}_{7} \mathrm{O}_{24}\right)_{4}\right] \cdot 34 \mathrm{H}_{2} \mathrm{O}$ & $P \bar{\imath}$ & $\left\{\mathrm{M}_{5}\left(\mathrm{Mo}_{7}\right)\right\}$ & $\begin{array}{l}\text { Trigonal prism, } \\
\text { Tricapped } \\
\text { trigonal prism }\end{array}$ & 33 \\
\hline
\end{tabular}

Abbreviations used: bpp $=1$,3-bis(4-pyridyl)propane; 2-amp $=2$-aminopyridine; DMSO $=$ dimethylsulfoxide; 3 -amp $=$ 3-aminopyridine; $\mathrm{Im}=$ imidazole; $\mathrm{hmt}=$ hexamethylenetetramine; ahmt $=N$-(aminomethylene)-hexamethylenetetramine

LabRAM HR Raman spectrometer in the range 3500$100 \mathrm{~cm}^{-1}$ at a resolution of $4 \mathrm{~cm}^{-1}$. The sample was finely powdered and pressed into a small depression on a metal disc and mounted on the sample compartment. The UV-Vis absorption spectra were recorded using UV-3600 Shimadzu UV-Vis spectrometer. Elemental analyses $(\mathrm{C}, \mathrm{H}$ and $\mathrm{N}$ ) were performed on a Variomicro cube CHNS analyser. X-ray powder patterns were measured on a Rigaku Miniflex II powder diffractometer using $\mathrm{Cu}-\mathrm{K}_{\alpha}$ radiation with $\mathrm{Ni}$ filter. Simultaneous thermogravimetry (TG) and differential thermal analyses (DTA) of a powdered sample of $\mathbf{1}$ were performed in alumina crucible in the temperature range of $25^{\circ} \mathrm{C}$ to $800^{\circ} \mathrm{C}$, using a Netzsch STA- $409 \mathrm{PC}$ thermal analyzer, at a heating rate of $10^{\circ} \mathrm{C} / \mathrm{min}$. Cyclic voltammetry was performed in Electrochemical Workstation-CH Instrument (Inc. CHI6107), under inert atmosphere by using platinum as working electrode, platinum wire as counter electrode and saturated calomel electrode (SCE) as the reference with $0.2 \mathrm{M}$ $\mathrm{KCl}$ solution as supporting electrolyte. ESR study was carried out on a Bruker EMx/micro-x instrument at room temperature.

\subsection{Synthesis of $(\mathrm{hmtH})_{2}\left[\left\{\mathrm{Mg}\left(\mathrm{H}_{2} \mathrm{O}\right)_{5}\right\}_{2}\left\{\mathrm{Mo}_{7} \mathrm{O}_{24}\right\}\right] \cdot 3$ $\mathrm{H}_{2} \mathrm{O} 1$}

2.2a Method 1: Molybdic acid (1.134 g, $7 \mathrm{mmol})$ was taken in distilled water To this basic magnesium carbonate $(0.194 \mathrm{~g}, 0.4 \mathrm{mmol})$ was added. The 
reaction mixture was then heated on a water bath to obtain a clear solution. To the clear solution obtained, hmt ( $0.280 \mathrm{~g}, 2 \mathrm{mmol})$ was added with continuous stirring. The final reaction mixture was then kept on water bath at $100^{\circ} \mathrm{C}$ for $40 \mathrm{~min}$ after adjusting its $\mathrm{pH}$ to 5.5 by adding few drops of dilute hydrochloric acid. Reaction mixture was cooled and filtered and the colourless filtrate was kept aside for crystallization. Fine, colourless crystals separated out after $1 \mathrm{~h}$ and when kept for further crystallization, 1 was obtained (1.23 g) in $75 \%$ yield.

\section{2b Method 2: Ammonium heptamolybdate} $(1.236 \mathrm{~g}, 1 \mathrm{mmol})$ was dissolved in distilled water $(\sim 30 \mathrm{~mL})$ by heating at $80^{\circ} \mathrm{C}$ followed by the addition of magnesium chloride hexahydrate $(0.406 \mathrm{~g}, 2 \mathrm{mmol})$. To the resultant reaction mixture, hmt $(0.280 \mathrm{~g}$, $2 \mathrm{mmol}$ ) was added with continuous stirring. The final reaction mixture was then kept on water bath at $80^{\circ} \mathrm{C}$ for $30 \mathrm{~min}$ after adjusting its $\mathrm{pH}$ to 5.5 , by adding few drops of dilute hydrochloric acid. Reaction mixture was allowed to cool and filtered, and the colourless filtrate was kept aside for crystallization. Fine, colourless, crystals separated out after $1 \mathrm{~h}$ and when kept for further crystallization, 1 (1.203 g) was obtained in 73\% yield. Anal. Calcd for (1) (\%): C, 8.89; H, 3.23; N, 6.91; O, 36.52; Mo, 41.44; Mg, 3.0\%. Found \% (1): C, 15.48; H, 5.25; N, 17.96\%. IR data: 3447, 3186, 2963, 2891, 2405, 1834, 1658, 1466, 1440, 1377, 1300, 1259, 1236, 1149, 1061, 1010, 982, 917, 887, 832, 673, $574,486 \mathrm{~cm}^{-1}$. Raman data: 944, 894, 838, 363, 341, 279, 197, 145, $117 \mathrm{~cm}^{-1}$. DTA (in ${ }^{\circ} \mathrm{C}$ ): 184 (endo), 468(exo), 765 (endo).

\subsection{Crystal structure determination}

The intensity data were collected at room temperature using a Bruker Smart Apex CCD diffractometer with graphite monochromated $\mathrm{Mo}-\mathrm{K} \alpha$ radiation $(\lambda=0.71073 \AA)$ by the $\omega$-scan method. Integration and scaling of intensity data were accomplished using the program SAINT. ${ }^{34}$ The structure was solved with direct methods using SHELXS-97 ${ }^{35}$ and refinement was done against $\mathrm{F}^{2}$ using SHELXL-97. ${ }^{35}$ All non-hydrogen atoms were refined anisotropically. $\mathrm{H}$ atom attached to the $\mathrm{N}$ atoms of $(\mathrm{hmtH})^{+}$cation was located in a difference Fourier density map and refined isotropically. The $\mathrm{H}$ atoms of the methylene groups were located in a difference electron density map but were positioned geometrically and included as riding atoms. The $\mathrm{H}$ atoms attached to the lattice water molecules OW1 and OW2 could not be located. Technical details of data acquisition and selected refinement results are listed in table 2.

\section{Results and Discussion}

\subsection{Description of the crystal structure of 1}

The compound $(\mathrm{hmtH})_{2}\left[\left\{\mathrm{Mg}\left(\mathrm{H}_{2} \mathrm{O}\right)_{5}\right\}_{2}\left\{\mathrm{Mo}_{7} \mathrm{O}_{24}\right\}\right] \cdot 3 \mathrm{H}_{2} \mathrm{O}$ $\mathbf{1}$ is the first example of a structurally characterized $\mathrm{Mg}$ (II) complex containing a coordinated heptamolybdate. Compound $\mathbf{1}$ crystallizes in the centrosymmetric monoclinic space group $C 2 / c$ and its crystal structure consists of an unique $(\mathrm{hmtH})^{+}$monocation with all atoms located in general position, an independent $\left[\left\{\mathrm{Mg}\left(\mathrm{H}_{2} \mathrm{O}\right)_{5}\right\}_{2}\left\{\mathrm{Mo}_{7} \mathrm{O}_{24}\right\}\right]^{2-}$ dianion with the $\mathrm{Mo} 1$ atom located on a two fold axis and two unique water molecules OW1 and OW2, one of which (OW1) is situated on a twofold axis (figure S1 in Supplementary Information). In view of the special position of the Mo1 and OW1 atoms, the asymmetric unit consists a half of the dianion, and a total of three lattice water molecules per formula unit. The metric parameters of the $(\mathrm{hmtH})^{+}$cation and the $\left\{\mathrm{Mo}_{7} \mathrm{O}_{24}\right\}$ unit are in the normal range (table $\mathrm{S} 1$ in Supplementary Information). In the complex dianion, the $\left[\mathrm{Mo}_{7} \mathrm{O}_{24}\right]^{6-}$ functions as a $\mu_{2}$-bridging bidentate ligand binding to two symmetry related $\left[\mathrm{Mg}\left(\mathrm{H}_{2} \mathrm{O}\right)_{5}\right]^{2+}$ units via $\mathrm{O} 16$ and $\mathrm{O}^{2} 6^{\mathrm{i}}$ (for symmetry code see figure 1), completing an octahedral arrangement around $\mathrm{Mg}$ (II) (figure 1).

The cis $\mathrm{O}-\mathrm{Mg}-\mathrm{O}$ angles vary from $84.71(15)$ to $98.47(18)^{\circ}$ while the trans $\mathrm{O}-\mathrm{Mg}-\mathrm{O}$ angles range from $173.82^{\circ}$ to $176.74^{\circ}$ indicating a distortion of the $\left\{\mathrm{MgO}_{6}\right\}$ octahedron. The $\mathrm{Mg}-\mathrm{O}$ bond distances range from 2.027(4) to 2.089(4) Å (table 3).

It is well documented that $\mathrm{Mg}$ (II) tends to form compounds containing the octahedral $\left[\mathrm{Mg}\left(\mathrm{H}_{2} \mathrm{O}\right)_{6}\right]^{2+}$ unit when isolated from aqueous medium as evidenced by the structural characterization of several compounds containing the hexaaquamagnesium(II) cation. A search of the Cambridge database reveals several such compounds (table S2). A few examples containing less than six coordinated water molecules around $\mathrm{Mg}$ (II) are known. ${ }^{36}$ The presence of $\left\{\left(\mathrm{H}_{2} \mathrm{O}\right)_{5} \mathrm{Mg}\right\}$ unit in the complex dianion can be attributed to the structure directing effect of the organic cation via $\mathrm{H}$-bonding interactions with the $\mathrm{O}$ atoms of heptamolybdate and the $\mathrm{O}$ atoms of coordinated water. Hexacoordination around $\mathrm{Mg}(\mathrm{II})$ is achieved due to the bridging bidentate coordination of the centrosymmetric $\left(\mu_{2}-\mathrm{Mo}_{7} \mathrm{O}_{24}\right)^{6-}$ ligand binding to two $\mathrm{Mg}(\mathrm{II})$ ions resulting in the formation of the complex dianion.

A scrutiny of the structure of 1 reveals a total of 15 weak hydrogen bonds comprising of seven $\mathrm{O}-\mathrm{H} \cdots \mathrm{O}$, 
Table 2. Crystal data and structure refinement for compound $\mathbf{1 .}$

\begin{tabular}{ll}
\hline Empirical formula & $\mathrm{C}_{12} \mathrm{H}_{46} \mathrm{Mg}_{2} \mathrm{Mo}_{7} \mathrm{~N}_{8} \mathrm{O}_{37}$ \\
Formula weight & 1614.77 \\
Temperature & $293(2) \mathrm{K}$ \\
Wavelength & $0.71073 \AA$ \\
Crystal system, space group & Monoclinic, $C 2 / c$ \\
Unit cell dimensions & $a=23.947(12) \AA, b=8.758(4) \AA$ \\
& $c=22.787(11) \AA$ \\
& $\alpha=90^{\circ}, \beta=115.793(1)^{\circ}, \gamma=90^{\circ}$ \\
Volume & $4303(4) \AA^{3}$ \\
Z, Calculated density & $4,2.493 \mathrm{~g}^{\circ} \mathrm{cm}^{3}$ \\
Absorption coefficient & $2.125 \mathrm{~mm}^{-1}$ \\
F(000) & 3152 \\
Crystal size & $0.30 \times 0.12 \times 0.25 \mathrm{~mm}^{3}$ \\
$\theta$ range for data collection & $1.89^{\circ}$ to $25.83^{\circ}$ \\
Limiting indices & $-29 \leq \mathrm{h} \leq 29,-10 \leq \mathrm{k} \leq 10,-27 \leq 1 \leq 27$ \\
Reflections collected /unique & $17547 / 4043[\mathrm{R}(\mathrm{int})=0.0415]$ \\
Completeness $\theta=25.83^{\circ}$ & $97.2 \%$ \\
Absorption correction & $\mathrm{Semi}-\mathrm{empirical} \mathrm{from} \mathrm{equivalents}$ \\
Refinement method & Full- matrix least-squares on $\mathrm{F}^{2}$ \\
Data / restraints / parameters & $4043 / 0 / 342$ \\
Goodness of fit on F $\mathrm{F}^{2}$ & 1.058 \\
Final R indices [I $>2 \sigma(\mathrm{I})]$ & $\mathrm{R} 1=0.0337$, wR2 $=0.0801$ \\
$\mathrm{R}$ indices (all data) & $\mathrm{R} 1=0.0382, \mathrm{wR} 2=0.0829$ \\
Largest diff. peak and hole & 1.061 and -0.618 e.A ${ }^{-3}$ \\
\hline
\end{tabular}

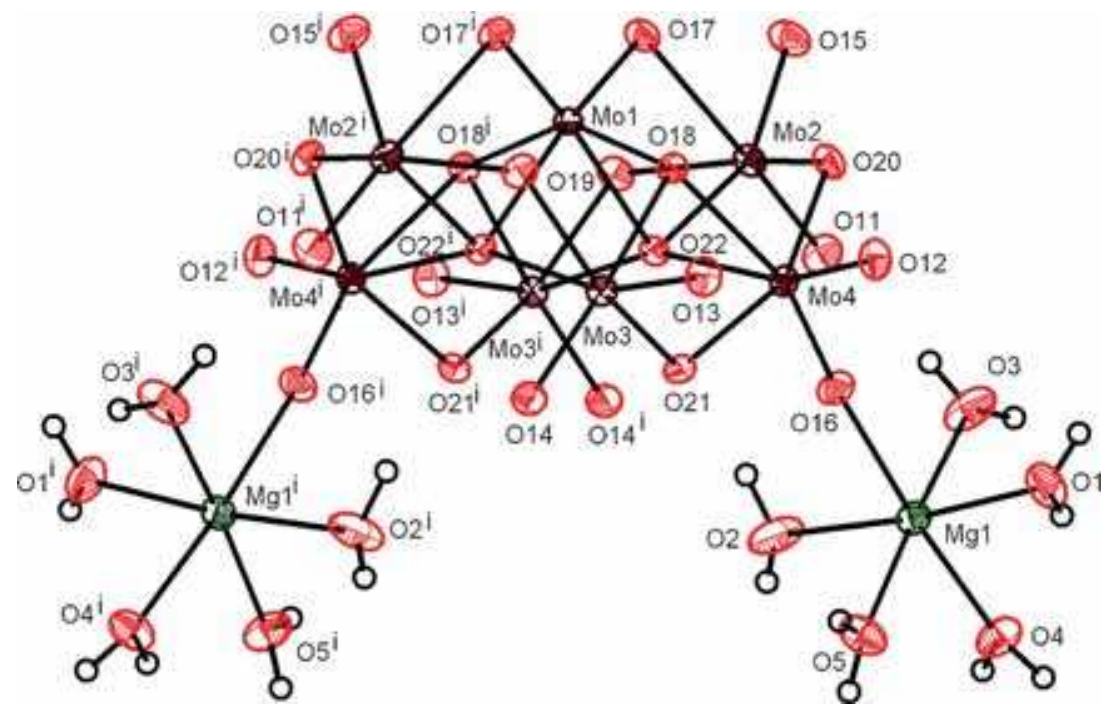

Figure 1. Representation of the anionic $\left[\left\{\mathrm{Mg}\left(\mathrm{H}_{2} \mathrm{O}\right)_{5}\right\}_{2}\left\{\mathrm{Mo}_{7} \mathrm{O}_{24}\right\}\right]^{2-}$ unit, showing atom labelling scheme. Thermal ellipsoids are drawn at the $30 \%$ probability level excepting for $\mathrm{H}$ atoms, which are shown as circles of arbitrary radius. Symmetry code: i) $\mathrm{x}, \mathrm{y}, 0.5-\mathrm{z}$.

three $\mathrm{O}-\mathrm{H} \cdots \mathrm{N}$, one $\mathrm{N}-\mathrm{H} \cdots \mathrm{O}$ and four $\mathrm{C}-\mathrm{H} \cdots \mathrm{O} \mathrm{H}$ bonding interactions (table S3) which interlink the organic cations, the complex dianions and lattice water molecules into in a supramolecular architecture (figure S2). In view of the inability to locate the $\mathrm{H}$ atoms attached to the lattice water a detailed description of the secondary interactions is not presented.
The ligational behaviour of $\left[\mathrm{Mo}_{7} \mathrm{O}_{24}\right]^{6-}$ towards other metals is well documented by the structural characterization of several compounds (table 1). It is interesting to note that in the closely related complexes $(\mathrm{hmtH})_{2}\left[\left(\mathrm{H}_{2} \mathrm{O}\right)_{5} \mathrm{M}\left(\mu_{2}-\mathrm{Mo}_{7} \mathrm{O}_{24}\right) \mathrm{M}\left(\mathrm{H}_{2} \mathrm{O}\right)_{4}\right] \cdot 2 \mathrm{H}_{2} \mathrm{O}$ $[\mathrm{M}=\mathrm{Mn}, \mathrm{Fe}, \mathrm{Zn}]$ all of which crystallize in the $C 2 / c$ space group the $\left\{\mathrm{Mo}_{7} \mathrm{O}_{24}\right\}$ unit links 
Table 3. Selected bond lengths $(\AA)$ and bond angles $\left(^{\circ}\right)$ for compound $\mathbf{1}$.

\begin{tabular}{llll}
$\begin{array}{l}\text { Bond lengths } \\
\mathrm{Mg}(1)-\mathrm{O}(1)\end{array}$ & $2.027(4)$ & $\mathrm{Mg}(1)-\mathrm{O}(4)$ & \\
$\mathrm{Mg}(1)-\mathrm{O}(2)$ & $2.055(5)$ & $\mathrm{Mg}(1)-\mathrm{O}(16)$ & $2.076(4)$ \\
$\mathrm{Mg}(1)-\mathrm{O}(3)$ & $2.059(4)$ & $\mathrm{Mg}(1)-\mathrm{O}(5)$ & $2.078(3)$ \\
$\mathrm{Bond}$ angles & & & \\
$\mathrm{O}(1)-\mathrm{Mg}(1)-\mathrm{O}(2)$ & $174.5(2)$ & $\mathrm{O}(2)-\mathrm{Mg}(1)-\mathrm{O}(16)$ & $84.73(18)$ \\
$\mathrm{O}(1)-\mathrm{Mg}(1)-\mathrm{O}(3)$ & $87.0(2)$ & $\mathrm{O}(3)-\mathrm{Mg}(1)-\mathrm{O}(4)$ & $89.12(17)$ \\
$\mathrm{O}(1)-\mathrm{Mg}(1)-\mathrm{O}(4)$ & $88.83(18)$ & $\mathrm{O}(3)-\mathrm{Mg}(1)-\mathrm{O}(5)$ & $176.74(19)$ \\
$\mathrm{O}(1)-\mathrm{Mg}(1)-\mathrm{O}(5)$ & $92.18(19)$ & $\mathrm{O}(3)-\mathrm{Mg}(1)-\mathrm{O}(16)$ & $84.71(15)$ \\
$\mathrm{O}(1)-\mathrm{Mg}(1)-\mathrm{O}(16)$ & $90.48(17)$ & $\mathrm{O}(4)-\mathrm{Mg}(1)-\mathrm{O}(5)$ & $87.70(18)$ \\
$\mathrm{O}(2)-\mathrm{Mg}(1)-\mathrm{O}(3)$ & $89.9(2)$ & $\mathrm{O}(4)-\mathrm{Mg}(1)-\mathrm{O}(16)$ & $173.82(16)$ \\
$\mathrm{O}(2)-\mathrm{Mg}(1)-\mathrm{O}(4)$ & $95.6(2)$ & $\mathrm{Mo}(4)-\mathrm{O}(16)-\mathrm{Mg}(1)$ & $171.9(2)$ \\
$\mathrm{O}(2)-\mathrm{Mg}(1)-\mathrm{O}(5)$ & $91.1(2)$ & $\mathrm{O}(16)-\mathrm{Mg}(1)-\mathrm{O}(5)$ & $98.47(18)$ \\
\hline
\end{tabular}

two $\left[\mathrm{M}\left(\mathrm{H}_{2} \mathrm{O}\right)_{\mathrm{x}}\right]^{2+}$ units but functions as a $\mu_{2}$-bridging tridentate ligand. The versatile coordination behaviour of the $\left[\mathrm{Mo}_{7} \mathrm{O}_{24}\right]^{6-}$ ligand can be evidenced by comparison of the structure of 1 with that of $(\mathrm{ImH})_{4}\left[\mathrm{Ca}\left(\mathrm{H}_{2} \mathrm{O}\right)_{6}\left(\mu_{2}-\mathrm{Mo}_{7} \mathrm{O}_{24}\right] \cdot 2(\mathrm{Im}) \cdot 3 \mathrm{H}_{2} \mathrm{O}\right.$ (entry No.29, table 1) in which the $\mu_{2}$-bridging bidentate coordination of the $\left\{\mathrm{Mo}_{7} \mathrm{O}_{24}\right\}$ unit results in a onedimensional structure unlike a discrete complex for $\mathbf{1}$. The extended structure is due to the fact that $\mathrm{Ca}$ (II) can adopt an eight coordination unlike hexacoordination around $\mathrm{Mg}(\mathrm{II})$ in $\mathbf{1}$.

\subsection{Synthetic aspects, spectral and thermal studies}

For the synthesis of a $\mathrm{Mg}(\mathrm{II})$ heptamolybdate compound the reaction of $\mathrm{H}_{2} \mathrm{MoO}_{4}$ (acid) with $\mathrm{MgCO}_{3}$ (base) was investigated (scheme 1). The insoluble molybdic acid starts dissolving in the presence of $\mathrm{MgCO}_{3}$ when heated to $100^{\circ} \mathrm{C}$ resulting in a clear solution. Addition of hmt at this stage to the reaction mixture, followed by crystallization at a $\mathrm{pH}$ of $\sim 5.5$ results in the formation of a crystalline compound. Analysis of the product reveals a stoichiometry of 2:2:7 for hmt:Mg:Mo. When the same mole ratio of reactants was employed by using alternate Mg source viz. $\left[\mathrm{Mg}\left(\mathrm{H}_{2} \mathrm{O}\right)_{6}\right] \mathrm{Cl}_{2}$ and a preformed heptamolybdate namely $\left(\mathrm{NH}_{4}\right)_{6}\left[\mathrm{Mo}_{7} \mathrm{O}_{24}\right] \cdot 4 \mathrm{H}_{2} \mathrm{O}$ and the reaction was performed in aqueous acid medium in the presence of $\mathrm{hmt}$, the earlier mentioned phase $\mathbf{1}$ containing Mg:Mo in 2:7 ratio is obtained. This indicates the high formation tendency of $\mathbf{1}$ in aqueous acidic medium irrespective of the Mo and Mg sources. All our efforts to isolate a pure magnesium polyoxomolybdate viz. $\left[\mathrm{Mg}\left(\mathrm{H}_{2} \mathrm{O}\right)_{\mathrm{n}}\right]_{3}\left[\mathrm{Mo}_{7} \mathrm{O}_{24}\right]$ were not fruitful indicating the importance of the organic cation for product formation. An elemental analysis reveals that 1 contains two monoprotonated hexamethylenetetramine $(\mathrm{hmtH})^{+}$ cations.

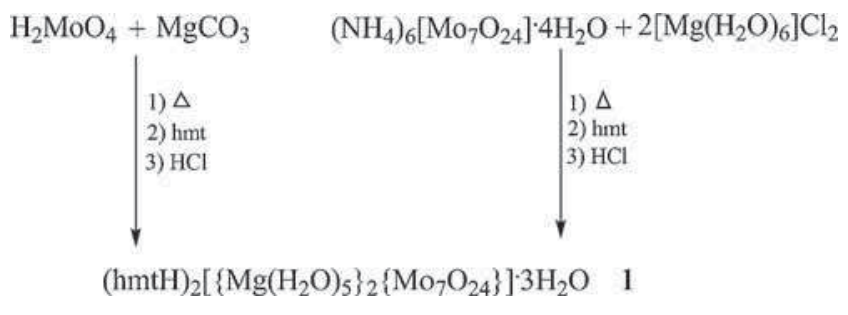

Scheme 1. Synthesis of a $\mathrm{Mg}(\mathrm{II})$ heptamolybdate compound 1.

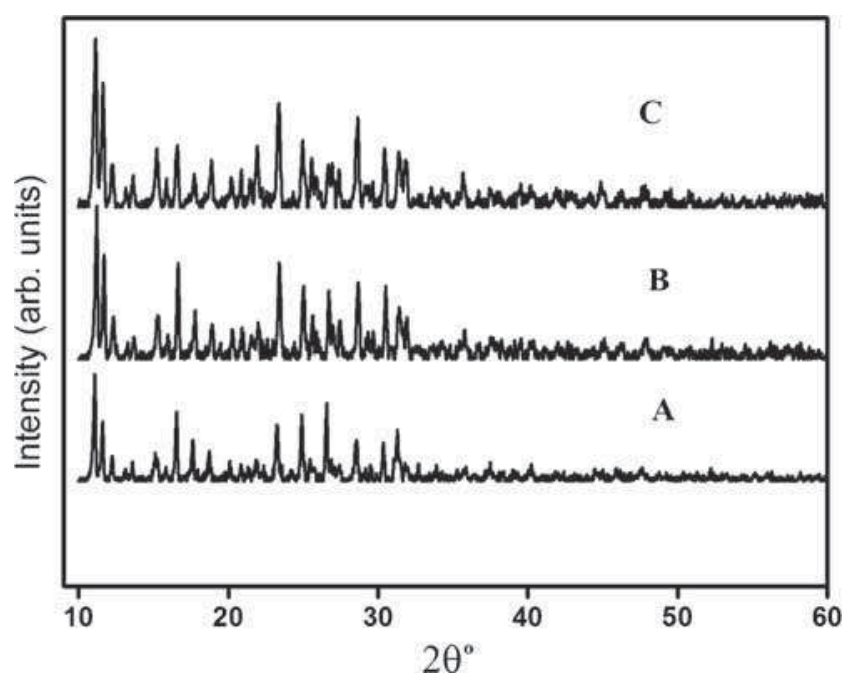

Figure 2. X-ray powder patterns of products obtained in method 1 (A), method 2 (B) and at $\mathrm{pH} 3$ (C).

In order to study the role of $\mathrm{pH}$ on the formation of $\mathbf{1}$, the reaction was performed in a more acidic medium $(\mathrm{pH} 3)$ and the product thus obtained was studied by its powder pattern. The formation of the same compound is revealed by identical powder patterns (figure 2) showing that compound $\mathbf{1}$ can be isolated in a wide $\mathrm{pH}$ range.

Our results are in agreement with literature data ${ }^{31}$ reporting on the isolation of $[\mathrm{hmtH}]_{2}\left[\left\{\mathrm{Zn}\left(\mathrm{H}_{2} \mathrm{O}\right)_{5}\right\}\right\}$ 
$\left\{\mathrm{Mo}_{7} \mathrm{O}_{24}\right\}\left\{\mathrm{Zn}\left(\mathrm{H}_{2} \mathrm{O}\right)_{4}\right] \cdot 2 \mathrm{H}_{2} \mathrm{O}$ at $\mathrm{pH}$ 3.0. The identical infrared, Raman and optical spectra and satisfactory elemental analysis add credence to the formation of the same product material irrespective of the source of $\mathrm{Mg}$ or Mo employed for synthesis.

\subsection{Spectroscopic and thermal characterization}

A comparison of the infrared spectrum of $\mathbf{1}$ with that of ammonium heptamolybdate tetrahydrate (figure S3) reveals the presence of the heptamolybdate core as evidenced by bands assignable to the various Mo-O vibrations at $982,887,832$ and $574 \mathrm{~cm}^{-1}$ as sharp peaks and weak bands in the region 917, 673 and $486 \mathrm{~cm}^{-1}$. The appearance of a broad band centred at $3186 \mathrm{~cm}^{-1}$ and a sharp peak at $1658 \mathrm{~cm}^{-1}$ assignable for the stretching and bending $\mathrm{O}-\mathrm{H}$ vibrations indicate the presence

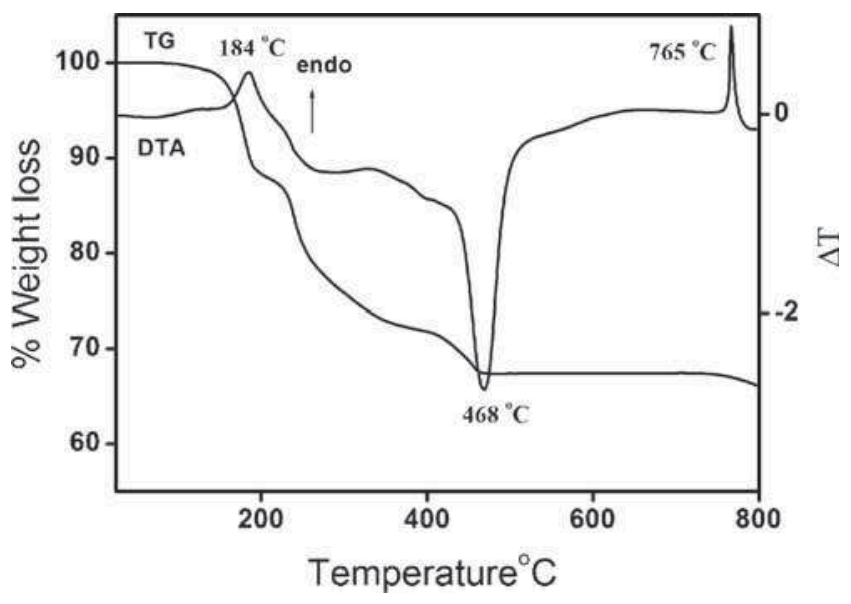

Figure 3. TG-DTA curves of $\mathbf{1}$.

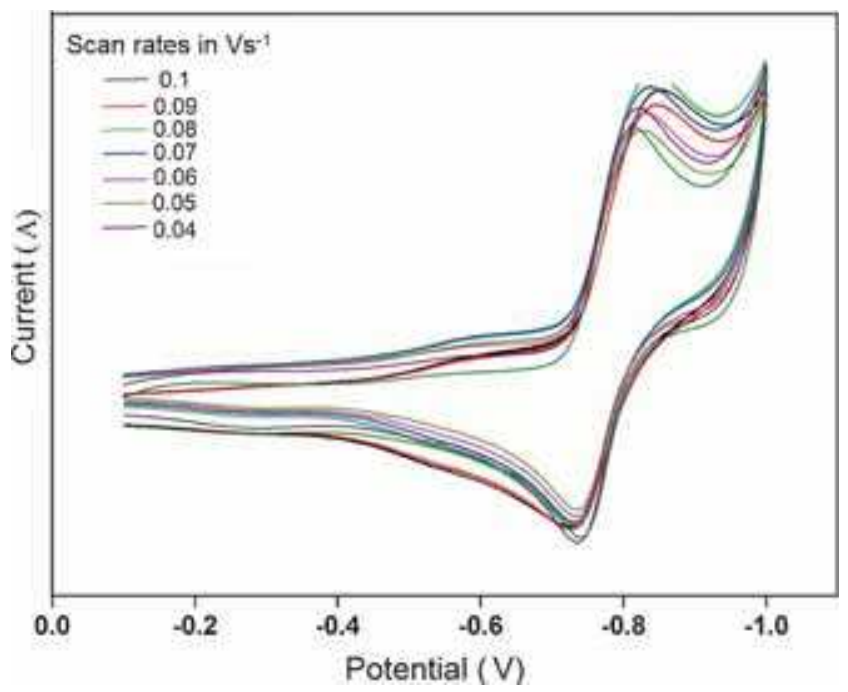

Figure 4. Cyclic voltammograms of $\mathbf{1}$ with scan rates of 0.1 to $0.04 \mathrm{Vs}^{-1}$ in the potential range of $-0.1 \mathrm{~V}$ to $-1.0 \mathrm{~V}$ in $0.2 \mathrm{M} \mathrm{KCl}$ solution. of water molecules. The Raman spectrum (figure S4) shows intense bands at 941,891 and $691 \mathrm{~cm}^{-1}$ due to Mo-O vibrations. The optical spectrum indicates the presence of heptamolybdate core in 1 (figure S5). Thermal studies of $\mathbf{1}$ show that the compound is thermally stable upto $140^{\circ} \mathrm{C}$. In accordance with this no mass loss is observed when a powdered sample of $\mathbf{1}$ is heated on a water bath at $100^{\circ} \mathrm{C}$. The DTA curve exhibits thermal events at 184,468 and $765^{\circ} \mathrm{C}$ (figure 3 ).

The endothermic peak at $184^{\circ} \mathrm{C}$ can be assigned for the loss of water molecules while the exothermic events can probably be assigned for the decomposition of organic moiety leaving residue of $67.30 \%$. The theoretically calculated percentage for the complete loss of water and organics for a residual composition $\left\{\mathrm{Mo}_{7} \mathrm{Mg}_{2} \mathrm{O}_{23}\right\}$ is found to be $67.39 \%$. In accordance with this, heating of 1 in a furnace at $600^{\circ} \mathrm{C}$ resulted in a residue $(67.15 \%)$ which on acidification followed by addition of hmt results in formation of $\mathbf{1}$.

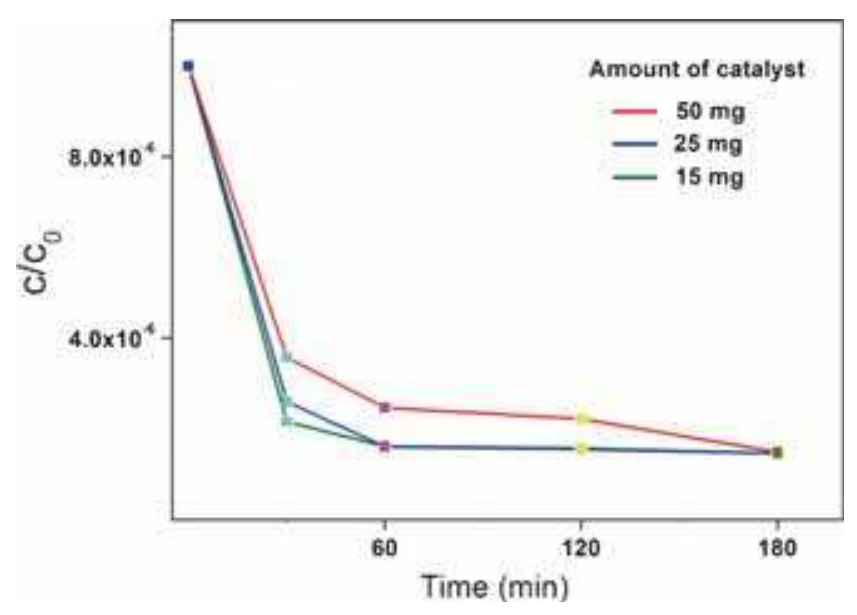

Figure 5. Time dependent decrease in the concentration of $\mathrm{RhB}$.

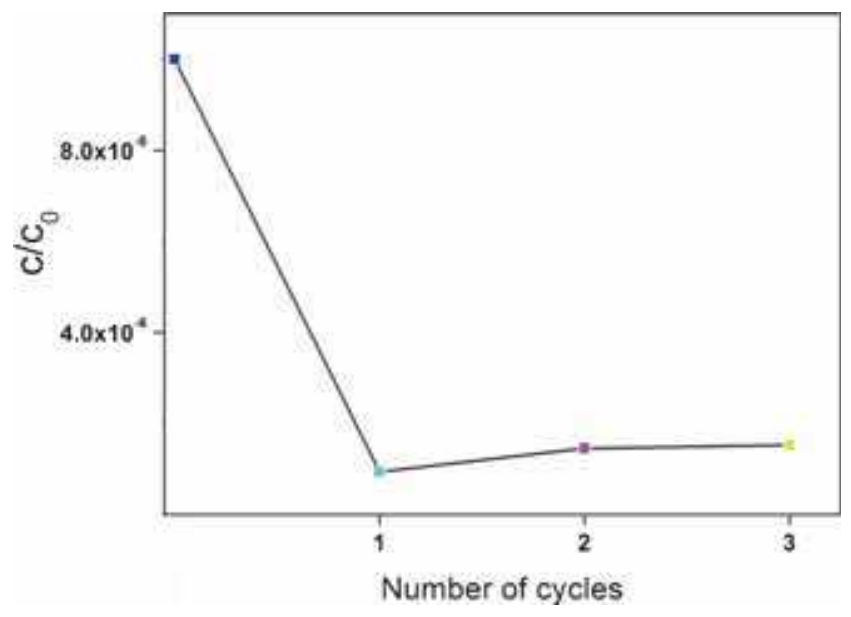

Figure 6. Recycling test of compound $\mathbf{1}$. 
Table 4. Degradation efficiency calculated for different amounts of $\mathbf{1}$.

\begin{tabular}{lccccc}
\hline \multirow{2}{*}{$\begin{array}{l}\text { Amount of } \\
\text { catalyst used }\end{array}$} & \multicolumn{5}{c}{ Degradation Efficiency $(\%)=\mathrm{c}_{0}-\mathrm{c} / \mathrm{c}_{0} * 100 \%$} \\
\cline { 2 - 6 } & $0 \mathrm{~min}$ & $30 \mathrm{~min}$ & $60 \mathrm{~min}$ & $120 \mathrm{~min}$ & $180 \mathrm{~min}$ \\
\hline $15 \mathrm{mg}$ & 0 & 78 & 83 & 84 & 86 \\
$25 \mathrm{mg}$ & 0 & 74 & 84 & 85 & 88 \\
$50 \mathrm{mg}$ & 0 & 64 & 75 & 78 & 85 \\
\hline
\end{tabular}

\subsection{Electrochemistry and photochemical investigations}

The cyclic voltammogram of $\mathbf{1}$ recorded at different scan rates (figure 4) indicates its quasireversible redox behaviour. The mean peak potential $\left(\mathrm{E}_{1 / 2}=\left(\mathrm{E}_{\mathrm{pa}}+\right.\right.$ $\left.\mathrm{E}_{\mathrm{pc}}\right) / 2$ ) of 1 calculated for a scan rate of $0.04 \mathrm{Vs}^{-1}$ is $-0.780 \mathrm{~V}$ while the observed $\mathrm{E}_{1 / 2}$ for the protonated salt of hmt namely $\mathrm{hmtHCl}$ is found to be $-0.379 \mathrm{~V}$ (figure S6). Hence the electrochemical process occurring in $\mathbf{1}$ can be ascribed to one electron redox process of Mo. The photosensitive nature of alkylammonium polyoxomolybdates in solid as well as in solution is well documented in the literature. ${ }^{37-40}$ Upon irradiation with sunlight for $15 \mathrm{~min}, \mathbf{1}$ turns into reddish brown $\mathbf{2}$, and again reverts back to colourless compound slowly in the presence of oxygen. The solid state UV-Vis spectrum of 1 (figure S7) exhibits a band at $312 \mathrm{~nm}$ which is characteristic of $\mathrm{O} \rightarrow$ Mo LMCT band. In the absorption spectrum of $\mathbf{2}$, in addition to this band a shoulder is observed at $490 \mathrm{~nm}$, which can be due to the photoreduction of Mo (VI) to Mo (V). The formation of Mo(V) is further confirmed by the ESR spectroscopy. The ESR spectrum of 2 (figure S8) exhibits characteristic $\mathrm{Mo}^{5+}$ signal, and the results are in accordance with literature data. $^{38}$

Thus, these investigations suggest its effectiveness as a photocatalyst. Hence the degradation of $\mathrm{RhB}$ in the presence of hydrogen peroxide as an oxidant under sunlight irradiation of $\mathbf{1}$ was investigated. The dye can be degraded to the extent of $88 \%$ after $3 \mathrm{~h}$ (figure 5) showing the good photocatalytic activity of $\mathbf{1}$.

The recycling test showed that the efficiency and the stability of the photocatalyst is good over three cycles (figure 6). Photocatalytic experiments were performed by taking different amounts of photocatalyst (table 4), with $0.5 \mathrm{~mL}$ of $30 \% \mathrm{H}_{2} \mathrm{O}_{2}$ for the degradation of $25 \mathrm{~mL}$ of $10^{-5} \mathrm{M}$ concentration (c) of $\mathrm{RhB}$ dye solution.

At given solar irradiation time intervals, a series of aqueous solutions of a certain volume were collected and separated through a centrifuge to remove suspended catalyst particles and then subjected to UV-Vis spectroscopy. The absorption spectra (figures S9, S10 and S11) show a decrease in the absorption as the irradiation time increases indicating the degradation of the dye. The degradation of organic dye was investigated three times and similar photocatalytic efficiencies were observed (figure 6). The high reproducibility of the results indicates the stability of $\mathbf{1}$ as photocatalyst, which is also evidenced by the nearly identical X-ray powder patterns (figure S12) of the recovered catalyst and the original compound $\mathbf{1}$. To ensure that the effective photocatalysis is the combined result of activation of catalyst by sunlight irradiation and $\mathrm{H}_{2} \mathrm{O}_{2}$ as an oxidant, the absorption spectra were studied under various conditions (figure S13). These results reveal that for the effective photocatalysis, $\mathrm{H}_{2} \mathrm{O}_{2}$ is essential in the absence of which no degradation occurs.

\section{Conclusion}

In summary, the synthesis, characterization and photochemistry of a new heptamolybdate supported magnesium-aqua coordination complex, using hexamethylenetetramine as structure directing agent, is reported.

\section{Supplementary Information}

Crystallographic data (excluding structure factors) for the structure of (1) reported herein have been deposited with the Cambridge Crystallographic Data Centre as supplementary publication no. CCDC 1049780. Copies of the data can be obtained, free of charge, on application to CCDC,12 Union Road, Cambridge CB2 1 EZ, UK. (Fax: +44-(0)1223336033; http://www.ccdc.cam.ac.uk/conts/retrieving. html; E-Mail:deposit@ccdc.cam.ac.uk).

Electronic supplementary information (for figures $\mathrm{S} 1-\mathrm{S} 13$, tables S1-S3 and checkcif file) is available at www.ias.ac.in/chemsci.

\section{Acknowledgments}

The authors thank Prof. S. K. Das, University of Hyderabad, for helpful discussions. SSK acknowledges University Grant Commission (UGC), New Delhi for awarding Basic Scientific Research (BSR) fellowship and for a three month stay under training visit 
programme at UGC Networking Resource Centre, School of Chemistry, University of Hyderabad.

\section{References}

1. Pope M T and Müller A 1991 Angew. Chem. Int. Ed. 30 34

2. Cronin L and Müller A 2012 Chem. Soc. Rev. 417333

3. Kortz U, Slageren A r J van, Schnacke J, Dalal N S and Dressel M 2009 Coord. Chem. Rev. 2532315

4. Müller A and Gouzerh P 2012 Chem. Soc. Rev. 417431

5. Long D, Tsunashima R and Cronin L 2010 Angew. Chem. Int. Ed. 491736

6. Pradeep C, Long D and Cronin L 2010 Dalton Trans. 39 9443

7. Miras H N, Yan J and Cronin L 2012 Chem. Soc. Rev. 417403

8. Song Y and Tsunashima R 2012 Chem. Soc. Rev. 41 7384

9. Yang H, Li G, Xu B, Liu T, Li Y, Cao R and Batten S 2009 Inorg. Chem. Commun. 12605

10. Wang J P, Zhao J W, Duan X Y and Niu J Y 2006 Cryst. Growth Des. 6507

11. Zhang Z X, Sadakane M, Murayama T, Izumi S, Yasuda N, Sakaguchi N and Ueda W 2014 Inorg. Chem. 53903

12. Zhang Z X, Sadakane M, Murayama T, Sakaguchi N and Ueda W 2014 Inorg. Chem. 537309

13. Zhang Z X, Sadakane M, Noro S, Murayama T, Kamachi T, Yoshizawa K and Ueda W 2015 J. Mat. Chem. A $\mathbf{3} 746$

14. Mialane P, Zhang G J, Mbomekalle I M, Yu P, Compain J D, Dolbecq A, Marrot J, Secheresse F, Keita B and Nadjo L 2010 Chem. Eur. J. 165572

15. Zhang L Z, Gu W, Dong Z, Liu X, Li B and Liu M L 2009 J. Solid State Chem. 1821040

16. Feng W, Zhang T R, Liu Y, Lu R, Zhao Y Y, Li T J and Yao J N 2002 J. Solid State Chem. 1695

17. Gamelas J A F, Cavaleiro A M V, Gomes E, Belsley M and Herdtweck E 2002 Polyhedron 212537

18. Wang X, Li F, Liu S and Pope M T 2005 J. Inorg. Biochem. 99452
19. Gerth H U V, Rompel A, Krebs Boos B J and Kaminsky C L 2005 Anti-Cancer Drugs 16101

20. Liu H Y, Wu H, Ma J F, Liu Y Y, Yang J and Ma J C 2011 Dalton Trans. 40602

21. Cotton F A, Wilkinson G, Murillo C A and Bochmann M 1999 In Advanced Inorganic Chemistry $6^{\text {th }}$ Edition (New York: John Wiley)

22. Cruywagen J J, Draaijer A G, Heyns J B B and Rohwer E A 2002 Inorg. Chim. Acta 331322

23. Wutkowski A, Srinivasan B R, Naik A R, Schütt C, Näther C and Bensch W 2011 Eur. J. Inorg. Chem. 2254

24. $\mathrm{Li} \mathrm{T}, \mathrm{Lu} \mathrm{J}$, Gao S and Cao R 2007 Inorg. Chem. Commun. 101342

25. Qu X, Xu L, Yang Y, Li F, Guo W, Jia L and Liu X 2008 Struct. Chem. 19801

26. Khenkin A M, Shimon L J W and Neumann R 2003 Inorg. Chem. $\mathbf{4 2} 3331$

27. Arumuganathan T, Srinivasarao A and Das S K 2010 Cryst. Growth Des. 104272

28. Li J, Liu Y, Luo J, Zhao J W, Ma P T and Niu J Y Russian J. Coord. Chem. 37849

29. Gili P, Luis P A L, Mederos A, Arrieta J M, Germain G, Castineiras A and Carballo R 1999 Inorg. Chim. Acta 295106

30. Long D L, Kögerler P, Farrugia L J and Cronin L 2005 Dalton Trans. 1372

31. Arumuganathan T, Srinivasarao A, Kumar T V and Das S K 2008 J. Chem. Sci. 12095

32. Bin Y W, Zhong L C and Hui Z H 2002 Chinese J. Struct. Chem. 21168

33. Wu S, Deng B, Jiang X, Li R, Guo J, Lai F, Huang X and Huang C 2012 J. Solid State Chem. 196451

34. Bruker 2001 SAINT and SMART Bruker AXS Inc., Madison, Wisconsin, USA

35. Sheldrick G M 2008 Acta Crystallogr. Sect. A 64112

36. Srinivasan B R, Shetgaonkar S Y and Näther C 2011 Z. Anorg. Allg. Chem. $\mathbf{6 3 7} 130$

37. Yamase T 1998 Chem. Rev. 98307

38. Yamase T 1982 Dalton Trans. 1987

39. Meng X, Qin C, Wang X L, Su Z M, Li B and Yang Q H 2011 Dalton Trans. 409964

40. Zhang Z, Yang J, Liu Y Y and Ma J F 2013 Cryst. Eng. Comm. 153843 